\title{
Novel direct AMPK activator suppresses non-small cell lung cancer through inhibition of lipid metabolism
}

\author{
Xi Chen ${ }^{1}$, Chun Xie ${ }^{1}$, Xing-Xing Fan ${ }^{1}$, Ze-Bo Jiang ${ }^{1}$, Vincent Kam-Wai Wong ${ }^{1}$, Jia- \\ Hui $\mathrm{Xu}^{1}{ }^{1}$ Xiao-Jun $\mathrm{YaO}^{1}$, Liang Liu ${ }^{1}$ and Elaine Lai-Han Leung ${ }^{1,2,3}$ \\ ${ }^{1}$ State Key Laboratory of Quality Research in Chinese Medicine, Macau Institute for Applied Research in Medicine and Health, \\ Macau University of Science and Technology, Taipa, Macau SAR, China \\ ${ }^{2}$ Respiratory Medicine Department, Taihe Hospital, Hubei University of Medicine, Hubei, China \\ ${ }^{3}$ Guangzhou Institute of Respiratory Disease, State Key Laboratory of Respiratory Disease, The 1st Affiliated Hospital of \\ Guangzhou Medical College, Guangzhou, China \\ Correspondence to: Elaine Lai-Han Leung, email: Ihleung@must.edu.mo \\ Xiao-Jun Yao, email: xjyao@must.edu.mo \\ Liang Liv, email: lliu@must.edu.mo
}

keywords: novel AMPK activator; NSCLC; gefitinib-resistant; lipid metabolism

Received: June 27, $2017 \quad$ Accepted: August 23, $2017 \quad$ Published: October 09, 2017

Copyright: Chen et al. This is an open-access article distributed under the terms of the Creative Commons Attribution License 3.0 (CC BY 3.0), which permits unrestricted use, distribution, and reproduction in any medium, provided the original author and source are credited.

\section{ABSTRACT}

Drug resistance is becoming an obstacle in anti-cancer therapies. For target-based therapy of lung cancer, gefitinib, as the first generation of tyrosine kinase inhibitors (TKIs), demonstrated good initial response to the non-small cell lung cancer (NSCLC) patients whom harbors epidermal growth factor receptor (EGFR) mutation. However, within one year, additional EGFR mutation occurred, leading to eventual gefitinibresistance. Therefore, it is urgently to discover novel effective small molecule inhibitors for those patients. Abnormal energy metabolism is accepted as new cancer hallmark. Recently, a metabolism rate-limiting enzyme 5'-adenosine menophosphate-activated protein kinase (AMPK) has become a promising anti-cancer target. In this study, we have identified a novel direct AMPK agonist, D561-0775 from a compound library by using molecular docking screening technique. We demonstrated that D561-0775 exhibited significant inhibitory effect on gefitinib-resistant NSCLC cell lines but less cytotoxicity on normal cells. Furthermore, D561-0775 demonstrated a remarkable in vitro AMPK enzyme activation effect. Taken together, D561-0775 showed potential anti-cancer activity via inducing apoptosis, cell cycle arrest, suppressing glycolysis and cholesterol synthesis after activation of AMPK in gefitinib-resistant $\mathrm{H1975}$ cells. D561-0775 has provided a new chemical structure that could be developed as cancer drug for gefitinib-resistant NSCLC patients through inhibition lipid metabolism by directly targeting at AMPK directly.

\section{INTRODUCTION}

Cancer is becoming a major life-threatening global public health problem [1], of which lung cancer as a particularly serious cancer form contributed to $20 \%$ of all cancer death cases $[2,3]$. In addition, non-small cell lung cancer (NSCLC) is the most common histological type of lung cancer and dominates almost $85 \%$ of all lung cancer cases. Conventional therapy, such as surgery, chemotherapy, or radiotherapy, scarify normal cells during the curing progress are becoming unfavorable.
To avoid harmful side-effect on normal cell, target-based therapy is the mainstream of modern cancer therapy. For example, gefitinib is a clinically-marketed drug which acts as tyrosine kinase inhibitor to inhibit epidermal growth factor receptor (EGFR) activating signaling pathway. For the NSCLC patients who harbor activating substitution from leucine to arginine at amino acid 858 (L858R) point mutation and in-frame exon 19 deletion on EGFR, response well to gefitinib and these two common mutation are used a biomarkers for gefitinib prescription. However, gefitinib-resistance commonly happens due to 
further substitution mutation from threonine to methionine at amino acid position 790 (T790M) occurred after one year or less gefitinib treatment. Therefore, developing new treatment strategy to tackle gefitinib-resistance is urgently.

To solve this, many researchers focused on inhibiting cancer progression by hampering energetic consumption status. Compared to normal cells, cancer cells prefer using glycolysis even in normal condition. This phenomenon was often referred as the "Warburg effect" [4]. As a major cellular fuel sensor, the 5'-adenosine menophosphateactivated protein kinase (AMPK) regulates metabolic homeostasis. It is a trimer enzyme made up of one catalytic subunit $(\alpha)$ and 2 regulatory subunits $(\beta, \gamma)$. On activation, AMPK induces a series of metabolic changes to balance energy consumption and production intracellular. The essential role of AMPK has led to the development of numerous AMPK activators which might be used as novel drug candidates in the treatment of AMPK related disorders, diabetes, obesity, and other metabolic diseases, as well as cancer [5-9].

Activated AMPK adjusts its downstream channels through the cascade (e.g. acetyl-CoA carboxylase (ACC), mechanistic target of rapamycin (mTOR), tuberous sclerosis $1 / 2(\mathrm{TSC} 1 / 2)$ to induce NSCLC cell death by producing material and energy situation [10]. AMPK could affect cell cycle [11], cell proliferation [12], and cell survival [10], also involve in the mitochondrial biogenesis [13] on NSCLC. AMPK responds to an increased AMP/ ATP ratio by turning on ATP-generating pathway, while turning off ATP-consuming one [14]. It directly switches from an anabolic to a catabolic state to save emergency of lacking energy. Thus, AMPK could be activated by its upstream Ser/Thr protein kinase, mainly the tumor suppressor liver kinase B 1 (LKB1) and the calcium/ calmodulin-dependent protein kinase kinase- $\beta(\mathrm{CaMKK} \beta)$ $[15,16]$, low energy status (e.g. lack of oxygen, glucose or ATP) [14, 17, 18], and other AMPK activators. The mechanism of activation AMPK is ultimately to phosphorylate Threonine 172 site within the $\alpha$-subunit [19]. It was reported lots of AMPK activators, which are divided into 2 types, direct and indirect AMPK activators, according to their different effective sites on AMPK structure. The indirect activators (e.g. 2-Deoxy-D-glucose (2DG), 5-Aminoimidazole-4-carboxamide ribonucleotide (AICAR) resveratrol, biguanides, curcumin, activate AMPK via activation of its upstream to achieve [20-23] and some of them are clinically in use. However, these activators are known to have additional molecular targets and AMPK-independent effects.

In some reports, indirectly agonist for example, biguanides anti-cancer function was showed as AMPK independent manner [24]. Latest, Vincent et al. compared 6 typical AMPK agonists including directly (salicylate, A-769662) and indirectly (metformin, phenformin, AICAR, 2DG) on cellular functions associated with proliferating cells. They established only synthetic activator A-769662 led apoptosis and inhibited proliferation through activation of AMPK. Other AMPK activators (salicylate, metformin, phenformin, AICAR, $2 \mathrm{DG}$ ) of anticancer properties can not be attributed to AMPK dependent manner [25]. Those results implied that indirectly activate AMPK have unfavorable side effects. Thus, it is of highly importance to identify direct AMPK activator with effect on AMPK-dependent manner. Currently, very few direct activators were reported, for example, A-769662 and salicylate were reported to allosteric activate AMPK via straightly effecting AMPK's subunits $[26,27]$, however, they have not been launched into clinical trial yet at this moment.

In this study, we aim to apply high throughput molecular docking screening technique to identify novel AMPK direct activator from a compound database. Afterwards, we validated our compound by kinase-based and cell-based assays to confirm in vitro AMPK activation and anti-cancer effect of the compound on NSCLC cell lines. D561-0775, showed significantly direct activation of AMPK. In addition, it also exhibited anti-cancer activity on gefitinib resistant NSCLC cell line H1975, which provided a new compound for future anti-cancer therapy.

\section{RESULTS}

\section{Alpha-AMPK activators are identified by molecular docking on a compound library}

We have performed molecular docking analysis on 130,000 compounds library database, and chosen 74 compounds with high binding affiliation to AMPK kinase domain. Then 3-(4, 5-Dimethylthiazol-2-yl)-2, 5-diphenyl tetrazolium bromide (MTT) assay was performed to determine the growth inhibition rate of these 74 compounds on H1975 cells. All compounds have been analyzed by molecular docking, and tested on H1975 cells which harbor EGFR T790M/L858R double mutation that confers to gefitinib resistance. Preliminary screening was shown by treating $\mathrm{H} 1975$ with all the compounds at the concentration range from $0,1.25,2.5,5,10$, and $20 \mu \mathrm{M}$ for $72 \mathrm{~h}$. Only 8 compounds showed $\mathrm{IC}_{50}$ values less than $10 \mu \mathrm{M}$ and were shortlisted in ascending order in Figure 1A and 1B. We then further performed Western blot to examine whether these 8 compounds could activate AMPK by phosphorylating Threonine 172 site. The concentrations used for these 8 compounds were 2.5 $\mu \mathrm{M}, 5 \mu \mathrm{M}, 5 \mu \mathrm{M}, 5 \mu \mathrm{M}, 10 \mu \mathrm{M}, 10 \mu \mathrm{M}, 10 \mu \mathrm{M}, 10 \mu \mathrm{M}$, respectively, based on their $\mathrm{IC}_{50}$ value obtained from MTT assays. By comparison, D561-0775, showed the strongly AMPK activation efficacy among the 8 compounds (Figure 1C).

We further used the CycLex AMPK Kinase Assay Kit to measure the activation level of AMPK by D561-0775. Data showed that D561-0775 significantly activated AMPK, while AMPK active kinase and AMP were used as positive 
control. As shown in Figure 1D, the activity of D561-0775 was significantly higher as AMP at $30 \mu \mathrm{M}$ in vitro, indicating that D561-0775 has AMPK activation activity.

The binding mode of D561-0775 docked into the active site of AMPK and chemical structure were shown in Figure 1E. The interactions between AMPK and D5610775 mainly consist of hydrophobic, polar and hydrogen bond interactions. The hydrophobic groups of D561-0775 form hydrophobic interactions with the side chain of L18, L31, I46 and T106. The polar groups of D561-0775 form polar interactions with the side chain of I46, L31, N48, R83, D88, S108, and N11. In addition, D561-0775 also forms hydrogen bonds with the backbone of I46 and N48 and the side chain of L31. Molecular docking data showed that D561-0775 was a direct AMPK activator by binding to the kinase pocket.

\section{D561-0775 possesses potent cytotoxicity in gefitinib-resistant NSCLC cell lines}

Since D561-0775 has the highest AMPK activation effect and showed cytotoxicity, we further tested in one more gefitinib-resistant NSCLC cell line (H820). H1975 contains L858R and T790M double mutations on EGFR. H820 harbors exon 19 in frame deletion and T790M double mutation on EGFR. These 2 cell lines are both insensitive to gefitinib. In order to know whether D5610775 has cytotoxicity on EGFR wild type cell line, we have used H1299 EGFR wild type cells, and CCD-19Lu which is normal human lung fibroblast cell as control.

As shown in Figure 2A, after $48 \mathrm{~h}$ treatment, D5610775 showed cytotoxicity on three NSCLC cell lines (H1975, H820 and H1299). The $\mathrm{IC}_{50}$ value of these three cell lines for $48 \mathrm{~h}$ treatment were $56.82 \pm 11.36 \mu \mathrm{M}$, $61.43 \pm 11.04 \mu \mathrm{M}$ and $63.27 \pm 9.74 \mu \mathrm{M}$. At $40 \mu \mathrm{M}$ and $80 \mu \mathrm{M}$ treatment dosages, it showed strong significantly difference in cytotoxicity between CCD-19Lu and H1975 cells (Figure 2C-2G).

After $72 \mathrm{~h}$ treatment, D561-0775 displayed cytotoxicity on all four cell lines. The $\mathrm{IC}_{50}$ value of these four cell lines were $9.59 \pm 1.73 \mu \mathrm{M}, 12.35 \pm 5.12 \mu \mathrm{M}$, $20.72 \pm 3.08 \mu \mathrm{M}, 15.13 \pm 1.95 \mu \mathrm{M}$, respectively for $72 \mathrm{~h}$ treatment (Figure 2B). Also, it showed significant difference when comparing EGFR mutant with EGFR wild-type cells (Figure 2H-2L). The EGFR status and $\mathrm{IC}_{50}$ value of each cell line after $48 \mathrm{~h}$ and $72 \mathrm{~h}$ treatment were presented in Figure 2M.

\section{D561-0775 activates the AMPK signaling pathway}

To further prove if D561-0775 is an AMPK activator, the phosphorylation level of AMPK at Threonine 172 was detected by Western blot on H1975 cells after $24 \mathrm{~h}$ and $48 \mathrm{~h}$ treatment of the drug. Results showed that D561-0775 phosphorylated AMPK in a dose-dependent
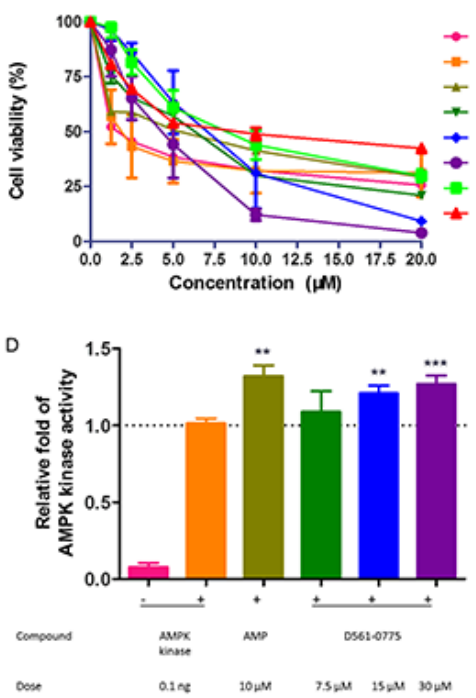

H1975 (L858/T790M mutation)

\begin{tabular}{|c|c|c|}
\hline \multirow{7}{*}{ 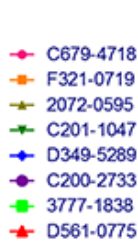 } & Drug number & $\mathrm{IC}_{50}$ value $(\mu \mathrm{M})(72 \mathrm{~h})$ \\
\hline & C679-4718 & $1.87 \pm 0.75$ \\
\hline & F321-0719 & $3.46 \pm 1.71$ \\
\hline & $2072-0595$ & $4.48 \pm 2.06$ \\
\hline & C201-1047 & $5.45 \pm 0.80$ \\
\hline & D349-5289 & $6.82 \pm 1.87$ \\
\hline & C200-2733 & $7.93 \pm 2.09$ \\
\hline & $3777-1838$ & $8.83 \pm 2.53$ \\
\hline & D561-0775 & $9.59 \pm 1.73$ \\
\hline
\end{tabular}

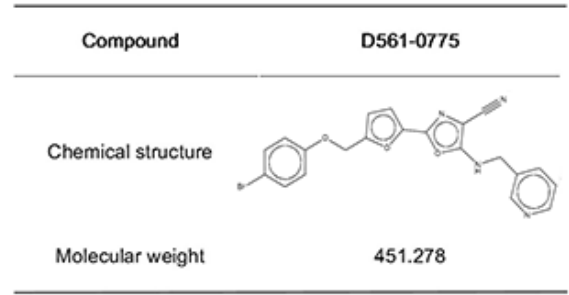

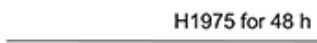
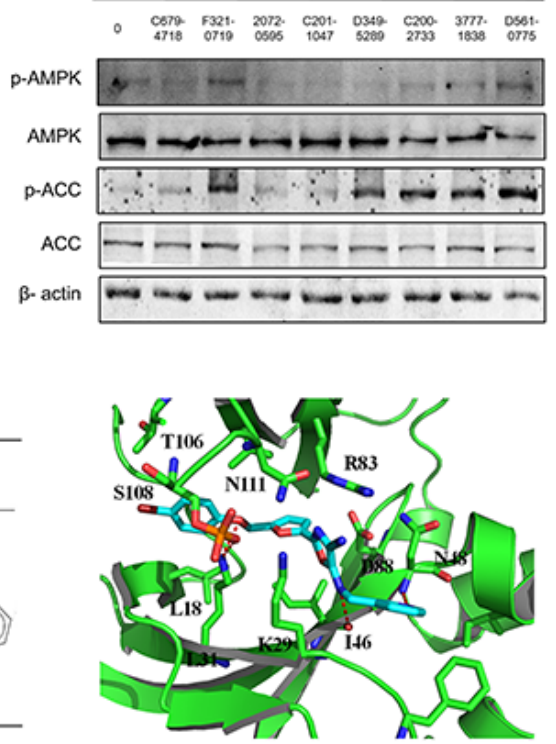

Figure 1: D561-0775 showed cytotoxicity on H1975, and had strongly activation effect on H1975. (A) The dose response curve of 8 compounds on $\mathrm{H} 1975$ cells after $72 \mathrm{~h}$ treatment. (B) $\mathrm{IC}_{50}$ values of 8 compounds on H1975 cells after $72 \mathrm{~h}$ treatment. (C) Western blot analysis of the protein level changes of p-AMPK, p-ACC, total AMPK, total ACC and $\beta$-actin after treatment with the 8 compounds for 48 h. (D) D561-0775 has a significantly activation of AMPK enzyme. (E) Chemical structure of D561-0775 and the binding mode of D561-0775 docked into AMPK. The AMPK protein was represented as cartoon. AMPK and key residues around the binding pocket were shown as sticks. The hydrogen bond was labeled as red dashed line. All data were expressed as mean $\pm \operatorname{SD}\left(\mathrm{n}=3,{ }^{* *} p<0.01,{ }^{* * *} p<0.001\right)$. All western blot images were cropped from full-length blots. 
manner. Activation of AMPK signaling leads to inhibition of downstream mTOR pathway. Our result showed that p-S6, the downstream protein of mTOR was reduced. Also, as shown in Figure 3A and 3C, D561-0775 induced phosphorylation of another AMPK downstream substrate ACC which was widely used as an AMPK activation marker [14]. Statistical analysis by Figure 3B and 3D, densitometry of western blot data indicated a significantly increasing of p-AMPK, p-ACC, via decreasing p-S6 after treated by D561-0775 for $24 \mathrm{~h}$ and $48 \mathrm{~h}$ in H1975.

\section{D561-0775 effectively induces apoptosis in H1975 cells}

To investigate whether D561-0775 can induce apoptosis in H1975 cells, we measured the level of apoptosis in H1975 after D561-0775 treatment using flow cytometric analysis and western blotting assay. As shown in Figure 4, all of these results revealed that D561-0775 significantly induced apoptosis in H1975. In
Figure $4 \mathrm{~A}$ and $4 \mathrm{~B}$, from the flow cytometry results, there was only $7.81 \%$ of cells undergoing apoptosis (Q2+Q3) in the control group, while cells were treated with 20 $\mu \mathrm{M}$ of D561-0775, apoptotic cells increased to $44.1 \%$ and in the $40 \mu \mathrm{M}$ treatment group, $48.92 \%$ cells were undergoing apoptosis. Moreover, as shown in Figure 4C and 4D, PARP was significantly cleaved and activated by D561-0775. While phopho-protein kinase B (p-AKT) were suppressed, and B-cell lymphoma 2 (Bcl-2) were decreased significantly, indicating induction of apoptosis.

Next, we further determine whether D561-0775 suppresses cell proliferation. Colony formation assay was performed. As shown in Figure 4E and 4F, D561-0775 treatment significantly attenuated colony formation in a dose-dependent manner. When cells were treated with $20 \mu \mathrm{M}$ of D561-0775, the percentage of colony formed remarkably decreased $60 \%$ when compared with the control group. It suggested that D561-0775 reduced cell proliferation and colony growth.
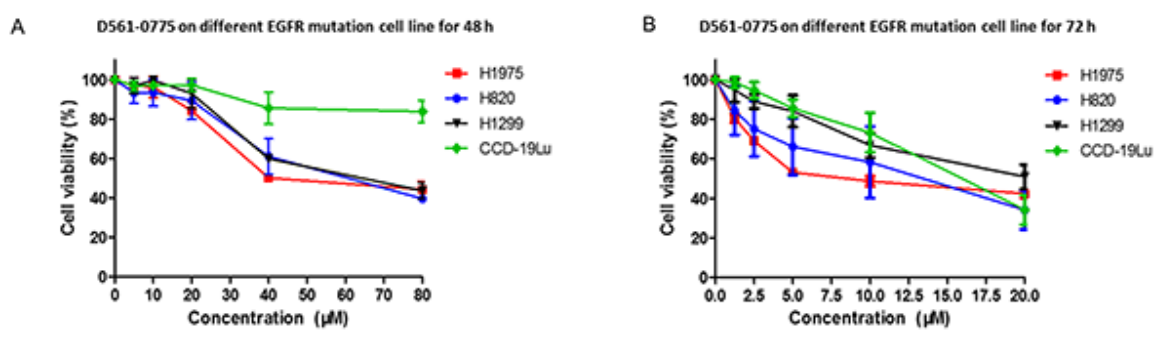

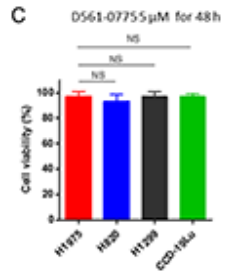

H
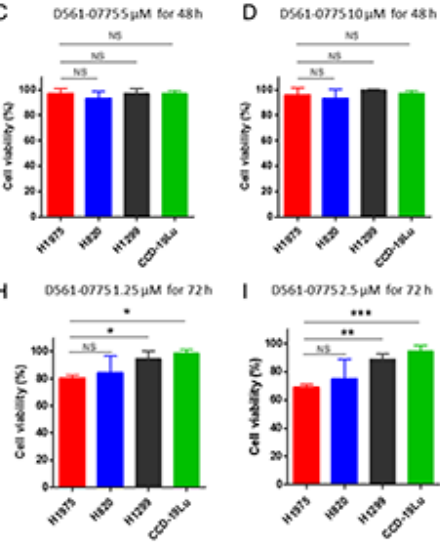

1 0561-077525um for $72 \mathrm{~h}$

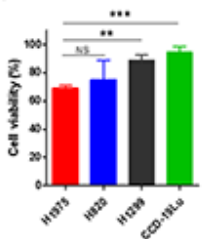

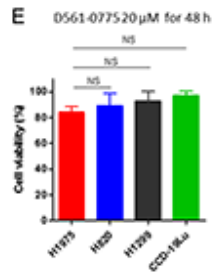

J $056107755 \mu \mathrm{M}$ for $72 \mathrm{~h}$

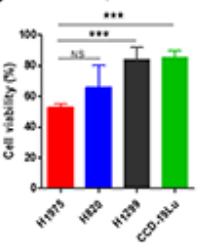

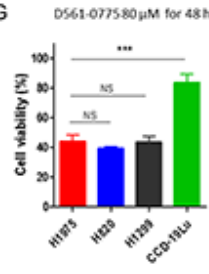

K 0561.077510um for $72 \mathrm{~h} \quad$ L

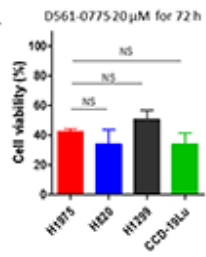

\begin{tabular}{|c|c|c|c|c|c|}
\hline Cell line & Cell type & EGFRgene status & Gefitinib sensitive & $I_{50}$ for $48 \mathrm{~h}(\mu \mathrm{M})$ & IC $_{50}$ for $72 \mathrm{~h}(\mu \mathrm{M})$ \\
\hline H1975 & NSCLC & L858R/7790M & Insensitive & $56.82 \pm 11.36$ & $9.59 \pm 1.73$ \\
\hline H820 & NSCLC & L858R/T79OM & Insensitive & $61.43 \pm 11.04$ & $12.35 \pm 5.12$ \\
\hline H1299 & NSCLC & Wild type & Sensitive & $63.27 \pm 9.74$ & $20.72 \pm 3.08$ \\
\hline CCD-19Lu & Normal lung cell & Wild type & N/A & $>80$ & $15.13 \pm 1.95$ \\
\hline
\end{tabular}

Figure 2: D561-0775 showed cytotoxicity on H1975, H820 and H1299 NSCLC cell lines, and normal lung cell CCD19Lu. (A) D561-0775 showed significant cytotoxic effect in a dose dependent manner on H1975, H820 and H1299, but did not affect CCD-19Lu at $80 \mu \mathrm{M}$ after $48 \mathrm{~h}$. (B) D561-0775 showed significant cytotoxic effect in a dose dependent manner on H1975, H820, H1299 and CCD-19Lu after $72 \mathrm{~h}$ treatment. (C-G) D561-0775 showed cytotoxicity in NSCLC cell lines at the concentration of $5 \mu \mathrm{M}, 10 \mu \mathrm{M}, 20$ $\mu \mathrm{M}, 40 \mu \mathrm{M}, 80 \mu \mathrm{M}$ after $48 \mathrm{~h}$ treatment. (H-L) D561-0775 showed cytotoxicity in NSCLC cell lines at the concentration of $1.25 \mu \mathrm{M}, 2.5$ $\mu \mathrm{M}, 5 \mu \mathrm{M}, 10 \mu \mathrm{M}, 20 \mu \mathrm{M}$ after $72 \mathrm{~h}$ treatment. (M) The $\mathrm{IC}_{50}$ values of D561-0775 on four cell lines were listed. All data was presented as mean $\pm \mathrm{SD}\left(\mathrm{n}=3,{ }^{*} p<0.05,{ }^{* *} p<0.01\right)$. 

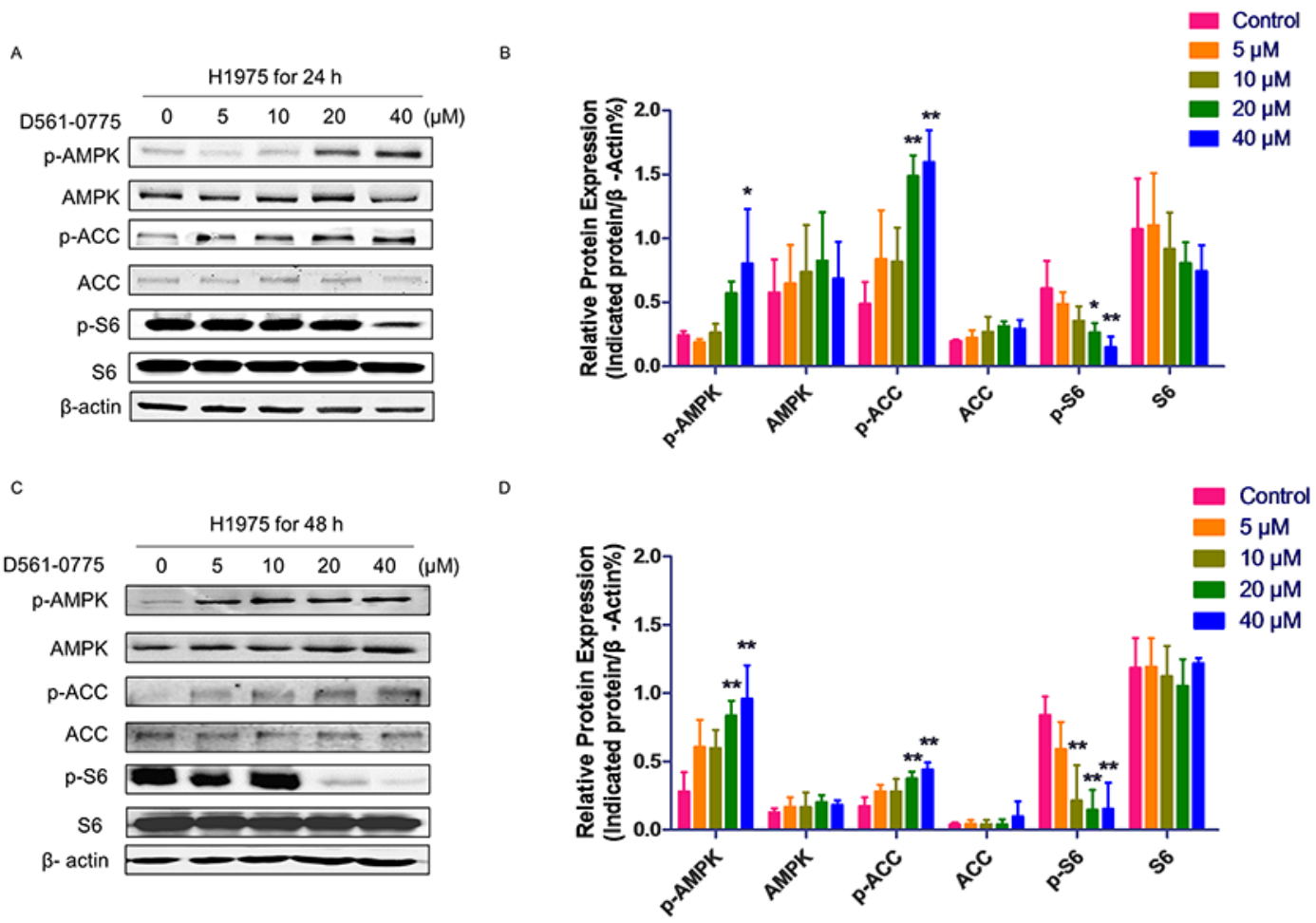

Figure 3: D561-0775 activated AMPK and its downstream signaling molecules. (A \& C) D561-0775 phosphorlated AMPK, ACC, and S6 on H1975 for $24 \mathrm{~h}$ and 48 h. (B \& D) Statistical analysis of p-AMPK, AMPK, p-ACC, ACC, p-S6 after 24 h and 48 h. All data was presented as mean $\pm \mathrm{SD}\left(\mathrm{n}=3,{ }^{*} p<0.05,{ }^{* *} p<0.01\right)$. All western blot images were cropped from full-length blots.
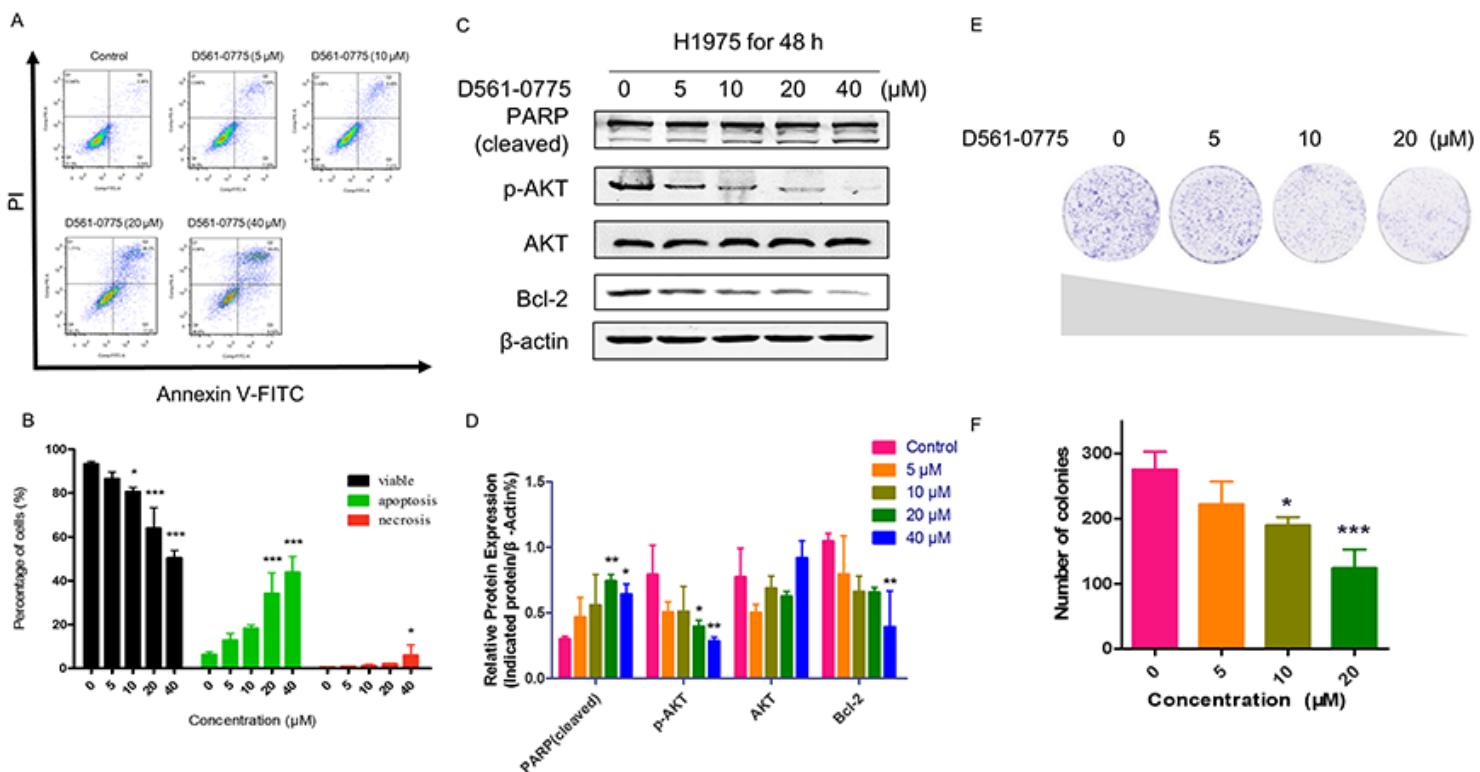

Figure 4: D561-0775 significantly induced apoptosis in H1975. (A) Flow cytometric analysis of the apoptosis level after D5610775 treatment for $48 \mathrm{~h}$. (B) Statistical analysis result of apoptosis data. (C) PARP was cleaved by D561-0775, while p-AKT, Bcl-2 were decreased by treating with D561-0775 for 48 h. (D) Statistical analysis of the densitometry of the signals of cleaved PARP, p-AKT, AKT, Bcl-2. (E) Photomicrographs of colony formation assay data after treatment with D561-0775 at different doses $(0,5,10,20 \mu \mathrm{M})$. (F) Statistical analysis of colony formation assay. All data was presented as mean $\pm \operatorname{SD}\left(\mathrm{n}=3,{ }^{*} p<0.05,{ }^{* *} p<0.01,{ }^{* * *} p<0.001\right)$. All western blot images were cropped from full-length blots. 

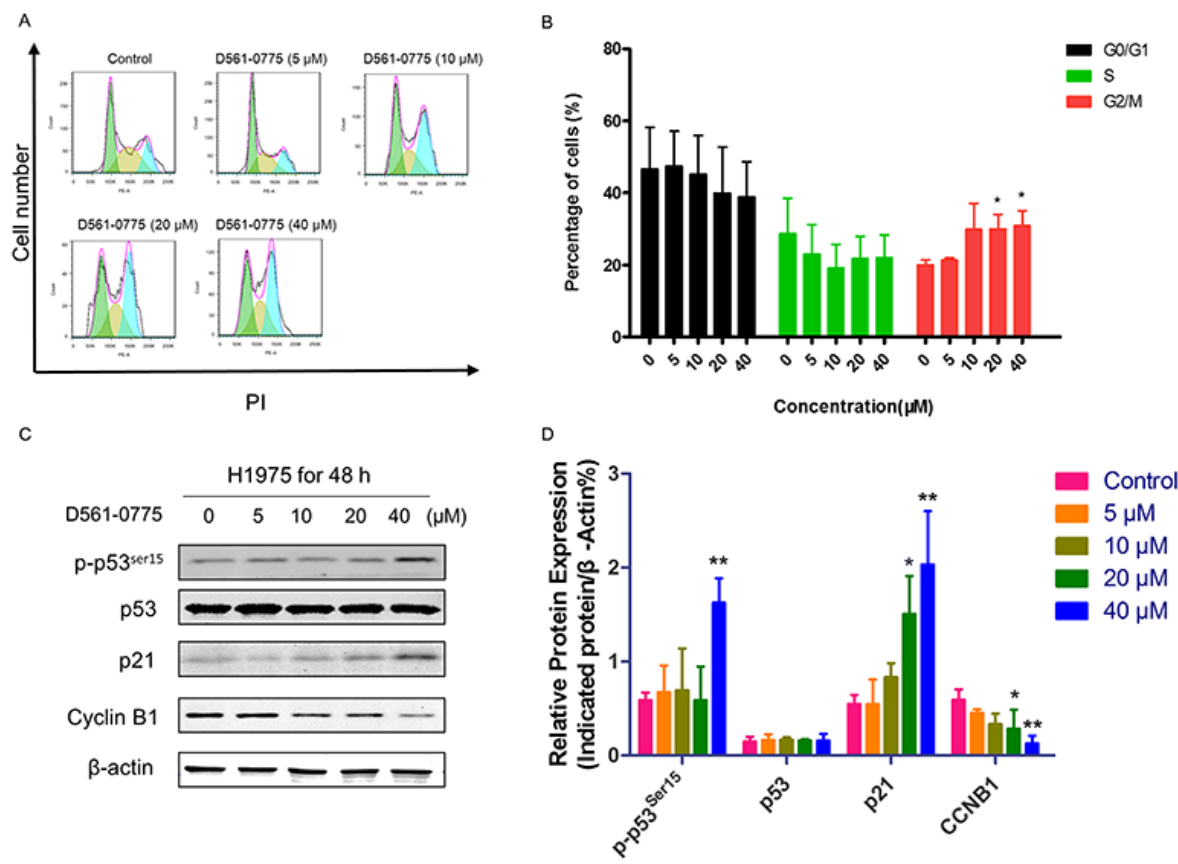

Figure 5: D561-0775 induced cell cycle arrest in H1975 cells. (A) H1975 cells were treated with D561-0775 at different concentration for $48 \mathrm{~h}$. (B) Statistical analysis of cell cycle distribution after $48 \mathrm{~h}$ drug treatment. (C) Western blot analysis of the protein levels of $\mathrm{p}-\mathrm{p} 53^{\operatorname{ser} 15}, \mathrm{p} 53, \mathrm{p} 21$, Cyclin B1 and $\beta$-actin after $48 \mathrm{~h}$ drug treatment. (D) Statistical analysis of the densitometry signals of $\mathrm{p}-\mathrm{p} 53^{\operatorname{ser} 15}, \mathrm{p} 53, \mathrm{p} 21$ and Cyclin B1. All data was presented as mean $\pm \mathrm{SD}\left(\mathrm{n}=3,{ }^{*} p<0.05,{ }^{* *} p<0.01\right)$. All western blot images were cropped from full-length blots.

A

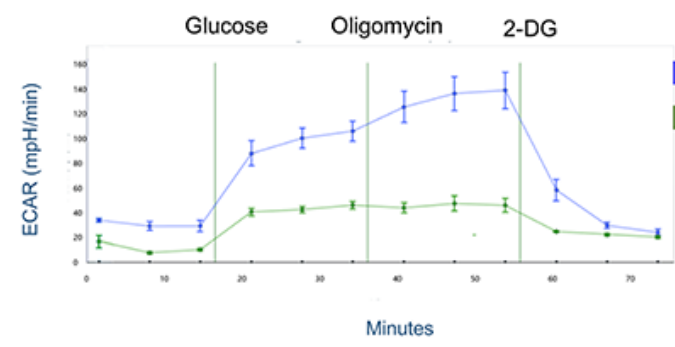

C

$\mathrm{H} 1975$ for $48 \mathrm{~h}$

Control

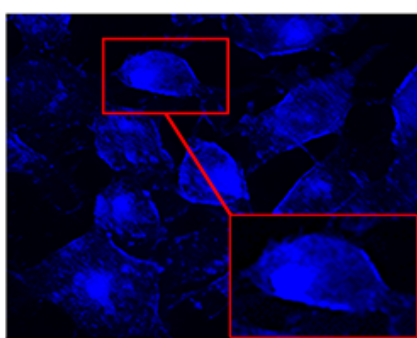

Control

D561-0775 $(20 \mu \mathrm{M})$

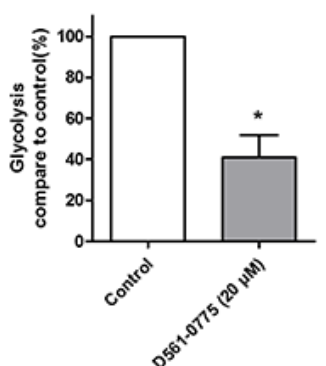

$\mathrm{H} 1975$ for $48 \mathrm{~h}$

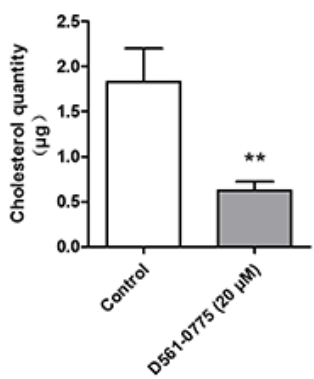

Figure 6: D561-0775 suppressed glycolysis and cholesterol synthesis in H1975. (A) The ECAR value decreased after treatment with D561-0775 for $48 \mathrm{~h}$. (B) The statistical analysis result of glycolysis for $48 \mathrm{~h}$. (C) Cholestrol staining after incubating with D561-0775 at $20 \mu \mathrm{M}$ on $\mathrm{H} 1975$ for $48 \mathrm{~h}$, magnified 40X dimension. (D) Quantification of the cholestrol level of H1975 after $48 \mathrm{~h}$ treatment with D5610775. All data were presented as mean $\pm \mathrm{SD}\left(\mathrm{n}=3,{ }^{*} p<0.05,{ }^{* *} p<0.01\right)$. 


\section{D561-0775 causes cell cycle arrest in H1975 cells}

To investigate the treatment mechanism of this AMPK agonist in H1975 cells, we further performed functional assays. To our knowledge, AMPK activation could awaken p53 [28], which has close relationship with p21. It arrested cell cycle during cell proliferation. After treatment with D561-0775 at the concentrations of 0,5, $10,20,40 \mu \mathrm{M}$ for $48 \mathrm{~h}$, cells were harvested and stained with Propidium iodide (PI). Flow cytometry analysis showed that $\mathrm{G} 2$ phase arrested were induced at $20 \mu \mathrm{M}$ and $40 \mu \mathrm{M}$ respectively (Figure 5A and 5B). Then we detected the protein expression of cell cycle related proteins in H1975. From Figure 5C and 5D, p-p53 ${ }^{\text {ser15 }}$, p21 increased while Cyclin B1 (CCNB1) decreased. It suggested that D561-0775 induced G2 phase arrest by activation of the AMPK/p53/p21 pathway.

\section{D561-0775 suppresses glycolysis and cholesterol synthesis in $\mathbf{H 1 9 7 5}$ cells}

To test if D561-0775 could inhibit glycolysis, we treated H975 cells with D561-0775 at $20 \mu \mathrm{M}$ for $48 \mathrm{~h}$ and compared the level of glycolysis with the untreated cells. We measured glycolysis by monitoring the extracellular acidification rate (ECAR) of cells in culture over $70 \mathrm{~min}$. In Figure 6A and 6B, it showed that after treating D5610775 for $48 \mathrm{~h}$, the ECAR line and glycolysis ratio were lower than that of the control group. Since ACC inhibition was triggered by D561-0775, the fatty acid synthesis and cholesterol synthesis were likely to be suppressed. To probe this, the level of cholesterol was measured. As shown in Figure 6C, cholesterol was stained by filipin and presented as blue dots. Compare to the control group, the number of blue dots and the luminosity intensity decreased in the treatment group. Next, cholesterol quantity assay was presented to imply that after treated by D561-0775, the cholesterol quantity decreased in H1975 cells. Western blot showed that the level of fatty acid decreased after D561-0775 treatment (Figure 6D). All data were presented as mean $\pm \mathrm{SD}\left(\mathrm{n}=3,{ }^{*} p<0.05\right)$.

\section{DISCUSSION}

AMPK serves as a fuel sensor that plays an important role in regulating energy metabolism in all cells under physiological and pathological circumstances. Theoretically, activation of AMPK could help cells to pass the energy crisis [29]. In support of this, AMPK was found to be required to maintain cellular proliferation in astrocytic tumors [30], facilitate stem cell self-renewal by fomenting the glycolytic metabolism of pluripotent cells [31], and has been shown to be crucial for the maintenance of metabolic viability of myc-activated cells $[32,33]$. Interestingly, after treating with a AMPK agonist, cancer cells were processing to death $[34,35]$. Many recent studies have found that the cellular metabolic state alone, which is critically determined by AMPK activity, can dramatically affect multiple cellular processes relevant to carcinogenesis and cancer progression [36-38]. However, AMPK seems to be playing a dual role, either as a tumor promoter or a tumor suppressor, depending on the cellular context [39].

In this study, we have applied molecular docking and has identified a new direct AMPK activator, designated as D561-0775, which showed inhibition of Gefitinib-resistant NSCLC. By using AMPK enzyme activity assay, we confirmed that D561-0775 has remarkable AMPK activation ability. According to AMPK Kinase activity results, our data showed that p-AMPK increased by incubating with D561-0775 in H1975 gefitinib-resistant cells. After that p-ACC increased, while p-S6 as mTOR downstream was extraordinary decreased. ACC and mTOR were considered as a marker of activation of AMPK. They reflect different function in cell, ACC, one of three key enzymes is comprised in the de novo fatty acid biosynthesis pathway [40]. Many cancer cells exhibit a markedly increased rate of fatty acid synthesis that is specifically lower in normal cells except adipocytes. Activation of ACC inhibits fatty acid synthesis and promotes fatty acid oxidation. Fatty acid synthase (FASN) is a key biosynthetic enzyme involved in lipogenesis and the production of long-chain fatty acids from ACC. However, in rapidly proliferating cancer cells, fatty acids can be synthesized de novo in order to provide lipids for membrane formation and energy production via $\beta$-oxidation and lipid modification of proteins. Besides, the suppression of FASN expression by activation of AMPK was previously reported [41]. For example, AICAR reduced expression of FASN and ACC resulting in inhibition of proliferation on prostate cancer cells [42]. Combined with the increasing of p-ACC and cholesterol staining result, it revealed that D561-0715 inhibits fatty acid synthesis through activation of AMPK/ ACC pathway. The mTOR is a serine/threonine protein kinase that regulates cell growth, cell proliferation, cell motility, cell survival, protein synthesis, autophagy, transcription [43]. Furthermore, overexpression of AMPK was also associated with a lack of mTOR level, resulting in suppression of cell growth, proliferation and protein synthesis [44-46].

To further examine how D561-0775 inhibited cell growth, we used quantitative flow cytometry analysis. It showed that D561-0775 remarkably increased the percentage of cells at G2 phase. That implied D561-0775 arrested cell cycle at G2 phase consequently inhibited mitosis. As a promising target, regulation of cell cycle checkpoints significantly contributed to treatment of cancer [47]. Whether cells can pass G2/M checkpoint, depends on the level of CCNB1, which is the initial activator and pivotal regulator, leading to regulation and activation of cyclin-dependent kinases 1 (CDK1)/CCNB1 complexes. 
Table 1: Summary of reported direct AMPK activators

\begin{tabular}{|c|c|c|c|c|c|c|}
\hline Compounds & $\begin{array}{l}\text { Chemical } \\
\text { structure }\end{array}$ & Binding subunit & Cell line & $\begin{array}{l}\text { Effect } \\
\text { time }\end{array}$ & Effect concentration & Reference \\
\hline Salicylate & & $\beta$ & A549 & $48 \mathrm{~h}$ & $103.64 \pm 4.59 \mu \mathrm{M}$ & {$[74]$} \\
\hline A-769662 & & $\beta$ & A549 & $48 \mathrm{~h}$ & $10 \mu \mathrm{M}$ & {$[13]$} \\
\hline Compound 991 & & $\begin{array}{l}\alpha \\
\beta\end{array}$ & AML & $48 \mathrm{~h}$ & $100 \mu \mathrm{M}$ & {$[65][63]$} \\
\hline MT 63-78 & & $\beta$ & PC3 & $48 \mathrm{~h}$ & $25-50 \mu \mathrm{M}$ & {$[75]$} \\
\hline PT-1 & & $\begin{array}{l}\alpha \\
\gamma\end{array}$ & $\begin{array}{c}\text { Hela } \\
\text { HEK293 }\end{array}$ & $\begin{array}{l}6 \mathrm{~h} \\
1 \mathrm{~h}\end{array}$ & $\begin{array}{c}20-40 \mu \mathrm{M} \\
100 \mu \mathrm{M}\end{array}$ & $\begin{array}{l}{[66]} \\
{[67]}\end{array}$ \\
\hline OSU-53 & & $\alpha$ & $\begin{array}{l}\text { MDA-MB-231/ } \\
\text { MDA-MB-468 }\end{array}$ & $\begin{array}{c}72 \mathrm{~h} \\
24-72 \mathrm{~h}\end{array}$ & $\begin{array}{c}5 \mu \mathrm{M} \\
5-10 \mu \mathrm{M}\end{array}$ & $\begin{array}{l}{[71]} \\
{[69]}\end{array}$ \\
\hline Compound-13 & & $\alpha$ & $\begin{array}{c}\text { Mouse hepatocytes } \\
\text { Gastric epithelial } \\
\text { cells }\end{array}$ & $\begin{array}{c}3 \mathrm{~h} \\
24 \mathrm{~h}\end{array}$ & $\begin{array}{c}10-100 \mu \mathrm{M} \\
10 \mu \mathrm{M}\end{array}$ & $\begin{array}{l}{[72]} \\
{[73]}\end{array}$ \\
\hline CNX-012-570 & Not shown & $\beta$ & $\begin{array}{c}\text { HepG2/C2C12, } \\
\text { 3T3L1 }\end{array}$ & $2-4 \mathrm{~h}$ & $0.3 \mu \mathrm{M}$ & [76] \\
\hline
\end{tabular}

Phosphorylation of these complexes further enforced cell cycle through the checkpoint and facilitated transition from G2 phase into mitosis [48, 49], which was consistent with our results. CCNB1 was decreased after treatment by D561-0775 $48 \mathrm{~h}$. In addition, activation of AMPK provides an inhibition effect on CDK and p21 [50]. It was reported that AMPK effected ataxia telangiectasia mutated (ATM) signals to mediate p53 and p21, targeted to cell cycle checkpoints [44, 51-54]. We observed that D561-0775 significantly increased p53 and p21, and it matches with our flow cytometry results of G2 phase cell cycle arrest. Taken together, our study indicated that D561-0775 induced H1975 cell arrest at G2 phase by AMPK activation to phosphate $\mathrm{p} 53$ and its downstream $\mathrm{p} 21$.

Consequently, apoptosis was observed after treatment with D561-0775, with suppression of AKT and Bcl-2, which belonged to the anti-apoptotic family [55]. Apoptosis played an important role in the development and homeostasis of multicellular organisms [56]. In the nervous system, apoptosis was required for normal development. AKT and Bcl-2 were considered antiapoptotic factors. The relationship between AMPK and AKT was complex. It was reported that AKT could inhibit AMPK activation [57], while Cui's group found that AMPK inducing cell apoptosis by inhibit PI3K/AKT/ mTOR pathway [58]. It has been reported that AMPK was a switch of p53, which was a tumor suppressor gene
[59]. It now appears that the primary action of p53 in apoptosis is to directly and indirectly regulate the activity of the Bcl-2 family proteins [60]. These experiment results supported our results, which demonstrated D561-0775 could activate AMPK and downstream p53 leading H1975 cells to apoptosis. Thus, it may explain effect of the colony formation suppression by D561-0775.

In principle, the metabolic dependencies of cancer cells can be exploited for cancer treatment [61]. D5610775 had cytotoxicity in gefitinib-resistant NSCLC cells. At 48 h, D561-0775 showed less toxicity on CCD-19Lu when comparing with EGFR mutant cells H1975 at $40 \mu \mathrm{M}$ and $80 \mu \mathrm{M}$. D561-0775 has selectivity between NSCLC cells and normal cells at $48 \mathrm{~h}$ treatment time point. There is still significantly difference in cytotoxicity between the EGFR wild-type and EGFR mutant cells at low drug dosage. Treatment selectivity may be due to different glycolysis phenotype among these cells. Since, EGFR activation up-regulated glycolysis in EGFR mutant cells but not in EGFR wild-type cancer cells and normal cells, thus, it is predictable that AMPK activation will suppress cell viability more in EGFR mutant cells and normal cells. Thus, we further used glycolysis stress kit to examine the glycolysis inhibitory effect of D561-0775. Our result supported the view from Faubert et. al. They mentioned that AMPK activation could negatively regulated Warburg effect in tumor cells [62]. 
Although, some small molecules have been reported from the literature as direct AMPK activators (Table 1). According to these reports, there is no gefitinib-resistant cells used as research object. As A-769662 was confirmed as an AMPK activator on the $\beta$ subunit [63], however, the catalytic site of AMPK locates at the $\alpha$ subunit [64]. Therefore, to design a compound directly binding to the $\alpha$ subunit can avoid the side effect. To our knowledge, there were only four $\alpha$ subunit binding activators being identified. Among these four, compound 991 was tested on AML cells only and was not tested on lung cancer, and the $\mathrm{IC}_{50}$ value of compound 991 is higher than D561-0775 [65]. Moreover, it was established that can not activate AMPK without the CBM domain, which is located at the $\beta$-subunit [63]. PT- 1 was considered as the $\alpha$ subunit binding activator [66]. However it not only bind to the $\alpha$ subunit but also the $\gamma$ subunit [67]. The effect of OSU-53 was only examined in thyroid carcinoma and myeloidderived suppressor cells [68-71]. Compound 13 was shown to inhibit hepatic lipid synthesis via an AMPKdependent manner [72], and inhibit Helicobacter pyloriinduced oxidative stresses leading to gastric epithelial cell apoptosis [73] but has not been tested in cancer cell yet.

Our compound is docking to bind on AMPK $\alpha$ subunit. Compare to these four activators, our compound D561-0775 chemical structure is simpler and could be easier to be synthesized. Small-molecule activators of AMPK will be invaluable for elucidating the functions of AMPK and validating the pharmaceutical importance of AMPK as a drug target. D561-0775 is a potential novel small-molecule activator that directly activates AMPK through regulation of $\alpha$ catalytic subunit and will be useful for evaluating the effects of AMPK under physiological and pathological conditions and studying its downstream signaling pathway.

In summary, our study has provided a new compound structure, D561-0775, which directly bind to AMPK $\alpha$ subunit and activate AMPK, exhibiting anti-cancer effect on gefitinib-resistant NSCLC cells. It induced apoptosis G2 phase arrest and suppressed glycolysis to inhibit cancer cell growth and proliferation. According our results, it suggested that D561-0775 is a potential and promising agent to treat gefitinib-resistant NSCLC patients by inhibition of glycolysis, cholesterol synthesis. Besides, it could be used potentially beneficial as tool drug for AMPK research.

\section{MATERIALS AND METHODS}

\section{Materials}

The compound library consisting 74 compounds were purchased from ChemDiv (San Diego, CA, USA). MTT powder and Dimethyl sulfoxide (DMSO) was purchased from Acros Organics (Morris Plains, NJ, USA). Adenosine 5'-Triphosphatase, filipin staining, chloroform and cholesterol quantity assay kit were purchased from Sigma Aldrich (St. Louis, MI, USA). Radioimmunoprecipitation (RIPA) lysis buffer $(10 \times)$ and the primary antibodies of $\beta$-Actin, CCNB1, p-ACC, total ACC, p21, p-S6, total S6, p-p53 ${ }^{\text {ser15 }}$, PARP, p-AKT, total AKT and Bcl-2 were purchased from Cell Signaling Technology (Danvers, MA, USA). The primary antibodies of p-AMPK, total AMPK, were purchased from Santa Cruz (Dallas, TX, USA). The secondary antibodies of anti-rabbit and anti-mouse were purchased from Odyssey (Belfast, ME, USA). Fluorescein-conjugated goat antirabbit and mouse anti-bodies were purchased from Odyssey (Belfast, ME, USA) and Invitrogen (Waltham, MA, USA). Annexin V/ Propidium iodide (PI) staining kit was purchased from BD Biosciences (San Jose, CA, USA). RNase A was purchased from Sigma Aldrich (St. Louis, MI, USA). Ten percent fetal bovine serum (FBS), $100 \mathrm{U} / \mathrm{ml}$ penicillin and $100 \mu \mathrm{g} / \mathrm{ml}$ streptomycin were purchased from Gibco (Oklahoma, ME, USA). A complete mini, EDTA-free tablet was from Roche (Mennheim, Germany). DCTM protein assay kit was purchased from Bio-Rad (Hercules, CA, USA). Nitrocellulose (NC) membrane was purchased from GE Healthcare (Waukesha, WI, USA). Crystal violet was purchased from Amresco (Solon, OH, USA). Glycolysis stress kit was purchased from seahorse (Seahorse Bioscience, MA, USA). AMPK kinase assay kit and AMPK $(\alpha 1 / \beta 1 / \gamma 1)$ active enzyme were from Cyclex. (CycLex Co., Ltd., Nagano, Japan).

\section{Cell culture}

H1975, H820, H1299 NSCLC cell lines and CCD19Lu normal lung fibroblast cell line were purchased from American Type Culture Collection (ATCC) (Manassas, VA, USA). The human normal lung fibroblast CCD-19Lu cells were grown in monolayer culture in MEM medium, whereas the three NSCLC cell lines were all grown in monolayer culture in RPMI 1640 medium. All culture media were supplemented with $10 \%$ FBS with $100 \mathrm{U} /$ $\mathrm{ml}$ penicillin and $100 \mathrm{~g} / \mathrm{ml}$ streptomycin. All cells were cultivated at $37^{\circ} \mathrm{C}$ in a humidified atmosphere of $5 \% \mathrm{CO}_{2}$.

\section{Molecular docking analysis}

Molecular docking calculation is performed to study the binding mode of D561-0775 to the adenosine 5'-monophsphate (AMP)-activated protein kinase (AMPK) using Glide program in Schrodinger software (Schrodinger, Inc., New York, NY, 2009). The structure of D561-0775 was processed by the LigPrep based on OPLS-2005 force field. The 3D structure of AMPK for molecular docking was retrieved from the Protein Data Bank (PDB ID: 4CFE) and was processed by the Protein Preparation Wizard module. D561-0775 was docked into the binding site of the AMPK with the standard precision (SP) scoring mode. The docking grid box was defined by 
centering on the compound 991 in the complex of AMPK and ligand (PDB ID: 4CFE). We used compound 991 as positive control which binds to $\alpha$ subunit.

\section{MTT assay}

Cells were seeded with $4 \times 10^{3}$ and $3 \times 10^{3}$ cells/well in a 96-well plate and allowed to adhere overnight, respectively. Cells were treated with various concentrations of compounds $(0,5,10,20,40,80 \mu \mathrm{M})$ with DMSO as vehicle control for $48 \mathrm{~h}$ and $(0,1.25,2.5$, $5,10,20 \mu \mathrm{M}$ ) for $72 \mathrm{~h}$. Ten $\mu \mathrm{l}$ of MTT solution were added to each well and incubated at $37^{\circ} \mathrm{C}$ for $4 \mathrm{~h}$. Then, 100 $\mu \mathrm{l}$ of resolved solution (10\% SDS and $0.1 \mathrm{mM} \mathrm{HCL}$ ) was added to each well and incubated at $37{ }^{\circ} \mathrm{C}$ for $4 \mathrm{~h}$ to solubilize the formazan crystals. Absorbance of plates was measured at $570 \mathrm{~nm}$ (absorbance) and $650 \mathrm{~nm}$ (reference) with Tecan microplate reader (Morrisville, NC, USA).

\section{AMPK enzyme activity assay}

We used the CycLex AMPK Kinase Assay Kit to detect the AMPK activation activity of D561-0775. According to the manufacturing instructions, on a 96well plate, $0.2 \mathrm{ng}$ of AMPK $(\alpha 1 / \beta 1 / \gamma 1)$ active enzyme was added into each well with D561-0775 (7.5, $15 \& 30 \mu \mathrm{M})$ or $10 \times$ of positive control, AMP $(100 \mu \mathrm{M})$ in kinase assay buffer $(50 \mu \mathrm{M}$ ATP \& $10 \mathrm{mM}$ DTT) and were incubated at $30^{\circ} \mathrm{C}$ for $20 \mathrm{~min}$. The reaction was then stopped by washing with buffer for 5 times. Then, anti-phosphomouse IRS-1 S789 monoclonal antibody was added to each well at room temperature for $30 \mathrm{~min}$. After washing with buffer for 5 times, HRP-conjugated anti-mouse $\operatorname{IgG}$ was added to each well at room temperature for $30 \mathrm{~min}$. After washing with wash buffer, the substrate reagent was incubated in wells at room temperature for 5-15 $\mathrm{min}$. Stop solution was added to each well before measuring absorbance at $450 / 550 \mathrm{~nm}$.

\section{Western blot analysis}

H1975 cells were plated at a cell density of $1.5 \times$ $10^{5}$ cells/well at a 6 -well plate and cultured overnight for attachment. Cells were harvested after stimulated by D561-0775 in different dosage for $48 \mathrm{~h}$. Cells were lysed in $1 \times$ RIPA lysis buffer with proteinase inhibitor and phosphatase inhibitors added, and were scraped off from the plate by a plastic cell scraper. All the lysate was mixed well and kept in ice then transferred to a new tube. The lysate was centrifuged at $4{ }^{\circ} \mathrm{C}$ at $12000 \mathrm{rpm}$ for $5 \mathrm{~min}$. After centrifugation, the suspension with protein lysate was kept on ice. Protein concentration was quantitatively measured by DCTM protein assay kit, the supernatant was transferred into a new tube and mixed with $5 \times$ loading buffer. Each sample was boiled at $100{ }^{\circ} \mathrm{C}$ for $5 \mathrm{~min}$. Twenty-five $\mu \mathrm{g}$ of each protein samples were loaded into the well of a $10 \%$ SDS-PAGE gel with one lane of $3 \mu \mathrm{l}$ protein molecular weight marker. The gel was run for 20 min at $80 \mathrm{~V}$ for stacking, and then added to $120 \mathrm{~V}$ for protein separation. After separation, the proteins from the gel were transferred to a $\mathrm{NC}$ membrane for $2 \mathrm{~h}$ at 300 $\mathrm{mA}$, the membrane was blocked with $5 \%$ non-fat milk diluted with $1 \times$ TBST $(0.1 \%$ Tween 20 in Tris-buffered saline) at room temperature for $1 \mathrm{~h}$ and washed with $1 \times$ TBST for three times. Membranes were incubated with primary antibodies at $1: 1000$ dilution at $4{ }^{\circ} \mathrm{C}$ overnight. After washing the membrane 3 times with $1 \times$ TBST, the membranes were incubated with secondary antibodies at 1:10000 dilutions for $1 \mathrm{~h}$ at room temperature. GAPDH was used as endogenous loading control for normalization. The signal intensity of the membranes was detected by LICOR Odyssey scanner (Belfast, ME, USA).

\section{Cell cycle analysis}

H1975 cells were plated with $1.5 \times 10^{5}$ cells/well at a 6-well plate and cultured overnight for attachment. Cells were treated with D561-0775 at 0, 5, 10, 20, 40 $\mu \mathrm{M}$ for $48 \mathrm{~h}$. After treatment, all cells were harvested by trypsinization, and collected by centrifugation. After removing all suspension, cells were washed by PBS. Cells pellets were re-suspended in $70 \%$ ethanol at $4{ }^{\circ} \mathrm{C}$ overnight. Cells were centrifuged at $1000 \mathrm{rpm}$ for $5 \mathrm{~min}$ to remove all the ethanol. Each cell pellet was re-suspended in $500 \mu \mathrm{l}$ PI staining solution at $37^{\circ} \mathrm{C}$ for $30 \mathrm{~min}$ in dark. Then, they were washed in PBS twice. Cells were resuspended in $300 \mu 11 \times$ binding buffer and transferred to the flow cytometer (BD FACS Aria III).

\section{Apoptosis assay}

H1975 cells $\left(1 \times 10^{5}\right.$ cells $/$ well $)$ were seeded in a 6-well plate for $24 \mathrm{~h}$, and treated with the indicated concentrations of D561-0775 for an additional 48 hours at $37^{\circ} \mathrm{C}$. After $48 \mathrm{~h}$, the cells were washed by ice-cold 1 $\times$ PBS once and harvested by trypsinization. Then cells were centrifuged, collected and resuspended in ice-cold 1 $\times$ PBS. After removing the supernatants, cell pellets were re-suspended in $100 \mu \mathrm{l} 1 \times$ Annexin -binding buffer. The cells were then double-stained with Annexin-V FITC and PI $(100 \mu \mathrm{g} / \mathrm{mL})$ of $2 \mu \mathrm{l}$ respectively for $15 \mathrm{~min}$ at room temperature in dark. After that, $300 \mu \mathrm{l} 1 \times$ Annexin-binding buffer was added to re-suspension. Apoptotic cells were quantitatively counted by a BD Aria III Flow Cytometer (BD Biosciences, San Jose, California, USA).

\section{Glycolysis stress test}

Glycolytic flux analysis was performed using the XF Glycolysis Stress Kit with the Seahorse Biosciences XF analyzer (Seahorse Bioscience, MA, USA). H1975 cells were trypsinized and $3 \times 10^{3}$ cells were plated per well of assay mini plate. After 48 h of D561-0775 treatment, medium was replaced with assay medium and incubated 
at $37^{\circ} \mathrm{C}$ without $\mathrm{CO}_{2}$ for $1 \mathrm{~h}$ to equilibrate the assay. After equilibration, three well-defined small molecule modulators of glycolysis, glucose and oligomycin (both are promoters of glycolysis) as well as 2-Deoxy-Dglucose (2DG) (a glycolysis inhibitor) were sequentially administered. Glycolysis leads to proton extrusion from the cells which results in the acidification of surrounding media, so the more glycolysis increasing, the $\mathrm{pH}$ range changed more strongly. The ECAR-extra cellular acidification rate was measured at specific time points and profile of the glycolytic flux were recorded in real time.

\section{Cholesterol staining assay}

H1975 cells were grown on glass coverslips in 6-well plate, each well of $1 \times 10^{5}$ cells /well. After treatment with D561-0775 at $20 \mu \mathrm{M}$ for $48 \mathrm{~h}$ at $37^{\circ} \mathrm{C}$. Cells were washed 3 times with PBS and then fixed with $4 \%$ paraformaldehyde (PFA) in PBS for $1 \mathrm{~h}$. Cells were rinsed 3 times with PBS and incubated with $1 \mathrm{ml}$ of $1.5 \mathrm{mg}$ glycine/ml PBS for 10 $\mathrm{min}$ at room temperature. Cells were stained with $1 \mathrm{ml}$ of filipin working solution for $2 \mathrm{~h}$ at room temperature in dark, then were washed with PBS for 3 times. Coverslips were mounted onto microscope slides with fluor save regent. Images were captured with Delta Vision Live Cell Imaging System with $40 \times$ objective magnification.

\section{Cholesterol quantity assay}

The quantification of cholesterol were determined using Sigma kit. Briefly, cells were harvested in chloroform buffer. The samples were centrifuged at $13000 \mathrm{~g}$ for $10 \mathrm{~min}$ to remove insoluble debris. Organic was collected and allowed to air dry on $50^{\circ} \mathrm{C}$ for $30 \mathrm{~min}$. Samples were vacuum dried for $2 \mathrm{~h}$ to remove traces of chloroform. The dried lipids were resuspended via vortexing in fatty acid assay buffer. Added $50 \mu \mathrm{l}$ sample to 96 well plate. Then added testing buffer into sample, mixed for $60 \mathrm{~min}$ without light in $37^{\circ} \mathrm{C}$. Samples further quantified by measuring absorbance at $670 \mathrm{~nm}$.

\section{Colony formation assay}

H1975 cells were seeded at a density of $1 \times 10^{3}$ cells/well in a 6-well plate, and cultured overnight for attachment. Cells were exposed on D561-0775 with concentration $(0,5,10,20 \mu \mathrm{M})$ for 10 days. Then medium was changed at every $72 \mathrm{~h}$. At the $10^{\text {th }}$ day, the colonies were washed by PBS once, and fixed with $4 \%$ PFA. The colonies were washed by PBS twice, stained with crystal violet solution for $20 \mathrm{~min}$, and washed. The number of colonies formed were counted in each group.

\section{Statistical analysis}

All data represent mean values of at least three independent experiments and were expressed as mean \pm
SD. The statistical significant differences were analyzed by one-way ANOVA followed by Dunnett's test for comparison tests, using Graph Prism Version 6.0 software (San Diego, CA, USA). ${ }^{*} p<0.05,{ }^{* *} p<0.01,{ }^{* * *} p<0.001$ were considered as significant.

\section{Abbreviations}

ACC, acetyl-CoA carboxylase; AICAR, 5-Aminoimidazole-4-carboxamide ribonucleotide; AKT, protein kinase B; AMPK, 5'-adenosine menophosphate -activated protein kinase; Bcl-2, b-cell lymphoma 2; CaMKK $\beta$, calcium/calmodulin-dependent protein kinase kinase- $\beta$; CCNB1, cyclin-dependent kinase 1; ECAR, extracellular acidification rate; EGFR, epidermal growth factor receptor; FASN, fatty acid synthase; LKB1, liver kinase $\mathrm{B} 1$; mTOR, mechanistic target of rapamycin; NSCLC, non-small cell lung cancer; PARP, poly ADP ribose polymerase; TSC $1 / 2$, tuberous sclerosis $1 / 2 ; 2 \mathrm{DG}$, 2-Deoxy-D-glucose.

\section{Author contributions}

Elaine Lai-Han Leung, Xiao-Jun Yao and Liang Liu designed the whole work and revised the manuscript. Xiao-Jun Yao designed the docking experiment. Jia-Hui $\mathrm{Xu}$ performed the compound screening experiment. ZeBo Jiang performed the Western Blot. Xing-Xing Fan helped to revise the manuscript. Chun Xie performed the cholesterol quantity assay and MTT assay of H1299 cells and CCD-19Lu cells. Vincent Kai-Wai Wong helped to perform the AMPK kinase assay and analyzed the data. $\mathrm{Xi}$ Chen performed the rest of the experiments, analyzed the data and wrote the initial draft of the manuscript. All authors reviewed and approved the final draft of the manuscript.

\section{ACKNOWLEDGMENTS}

We would like to acknowledge Prof. Yupo Ma for his valuable advice in this project.

\section{CONFLICTS OF INTEREST}

All authors declare no financial or commercial conflict of interest.

\section{FUNDING}

This work was supported by Macau Science and Technology Development Fund (Project No: 021/2013/ A1, 074/2011/A3 \& 082/2013/A3)

\section{REFERENCES}

1. American Cancer Society. Cancer Facts and Figures. 2015. 
2. Jemal A, Bray F, Center MM, Ferlay J, Ward E, Forman D. Global cancer statistics. CA Cancer J Clin. 2011; 61:69-90.

3. Chen W, Zheng R, Baade PD, Zhang S, Zeng H, Bray F, Jemal A, Yu XQ, He J. Cancer statistics in China, 2015. CA Cancer J Clin. 2016; 66:115-32.

4. Warburg O. On the origin of cancer cells. Science. 1956; 123:309-14.

5. Fryer LG, Parbu-Patel A, Carling D. The Anti-diabetic drugs rosiglitazone and metformin stimulate AMP-activated protein kinase through distinct signaling pathways. J Biol Chem. 2002; 277:25226-32.

6. Hotamisligil GS. Inflammation and metabolic disorders. Nature. 2006; 444:860-7.

7. Ji H, Ramsey MR, Hayes DN, Fan C, McNamara K, Kozlowski P, Torrice C, Wu MC, Shimamura T, Perera SA, Liang MC, Cai D, Naumov GN, et al. LKB1 modulates lung cancer differentiation and metastasis. Nature. 2007; 448:807-10.

8. Santos CR, Schulze A. Lipid metabolism in cancer. FEBS J. 2012; 279:2610-23.

9. Praveen P, Hulsmann H, Sultmann H, Kuner R, Frohlich H. Cross-talk between AMPK and EGFR dependent Signaling in Non-Small Cell Lung Cancer. Sci Rep. 2016; 6:27514.

10. Jin Q, Feng L, Behrens C, Bekele BN, Wistuba II, Hong WK, Lee HY. Implication of AMP-activated protein kinase and Akt-regulated survivin in lung cancer chemopreventive activities of deguelin. Cancer Res. 2007; 67:11630-9.

11. Wang Y, Qiu Q, Shen JJ, Li DD, Jiang XJ, Si SY, Shao RG, Wang Z. Cardiac glycosides induce autophagy in human non-small cell lung cancer cells through regulation of dual signaling pathways. Int J Biochem Cell Biol. 2012; 44:1813-24.

12. Siejka A, Barabutis N, Schally AV. GHRH antagonist MZ-5-156 increases the expression of AMPK in A549 lung cancer cells. Cell Cycle. 2011; 10:3714-8.

13. Shin DH, Choi YJ, Park JW. SIRT1 and AMPK mediate hypoxia-induced resistance of non-small cell lung cancers to cisplatin and doxorubicin. Cancer Res. 2014; 74:298-308.

14. Hardie DG, Carling D. The AMP-activated protein kinase-fuel gauge of the mammalian cell? Eur J Biochem. 1997; 246:259-73.

15. Woods A, Vertommen D, Neumann D, Turk R, Bayliss J, Schlattner U, Wallimann T, Carling D, Rider MH. Identification of phosphorylation sites in AMP-activated protein kinase (AMPK) for upstream AMPK kinases and study of their roles by site-directed mutagenesis. J Biol Chem. 2003; 278:28434-42.

16. Hawley SA, Pan DA, Mustard KJ, Ross L, Bain J, Edelman AM, Frenguelli BG, Hardie DG. Calmodulin-dependent protein kinase kinase-beta is an alternative upstream kinase for AMP-activated protein kinase. Cell Metab. 2005; 2:9-19.

17. Lamberts RR, Onderwater G, Hamdani N, Vreden MJ, Steenhuisen J, Eringa EC, Loer SA, Stienen GJ, Bouwman RA. Reactive oxygen species-induced stimulation of
5'AMP-activated protein kinase mediates sevofluraneinduced cardioprotection. Circulation. 2009; 120:S10-5.

18. Russell RR 3rd, Li J, Coven DL, Pypaert M, Zechner C, Palmeri M, Giordano FJ, Mu J, Birnbaum MJ, Young LH. AMP-activated protein kinase mediates ischemic glucose uptake and prevents postischemic cardiac dysfunction, apoptosis, and injury. J Clin Invest. 2004; 114:495-503.

19. Birnbaum MJ. Activating AMP-activated protein kinase without AMP. Mol Cell. 2005; 19:289-90.

20. Breen DM, Sanli T, Giacca A, Tsiani E. Stimulation of muscle cell glucose uptake by resveratrol through sirtuins and AMPK. Biochem Biophys Res Commun. 2008; 374:117-22.

21. Zhang FJ, Zhang HS, Liu Y, Huang YH. Curcumin inhibits Ec109 cell growth via an AMPK-mediated metabolic switch. Life Sci. 2015; 134:49-55.

22. Shaw RJ, Lamia KA, Vasquez D, Koo SH, Bardeesy N, Depinho RA, Montminy M, Cantley LC. The kinase LKB1 mediates glucose homeostasis in liver and therapeutic effects of metformin. Science. 2005; 310:1642-6.

23. Guigas B, Taleux N, Foretz M, Detaille D, Andreelli F, Viollet B, Hue L. AMP-activated protein kinaseindependent inhibition of hepatic mitochondrial oxidative phosphorylation by AICA riboside. Biochem J. 2007; 404:499-507.

24. Miller RA, Chu Q, Xie J, Foretz M, Viollet B, Birnbaum MJ. Biguanides suppress hepatic glucagon signalling by decreasing production of cyclic AMP. Nature. 2013; 494:256-60.

25. Vincent EE, Coelho PP, Blagih J, Griss T, Viollet B, Jones RG. Differential effects of AMPK agonists on cell growth and metabolism. Oncogene. 2015; 34:3627-39.

26. Goransson O, McBride A, Hawley SA, Ross FA, Shpiro N, Foretz M, Viollet B, Hardie DG, Sakamoto K. Mechanism of action of A-769662, a valuable tool for activation of AMP-activated protein kinase. J Biol Chem. 2007; 282:32549-60.

27. Hawley SA, Fullerton MD, Ross FA, Schertzer JD, Chevtzoff C, Walker KJ, Peggie MW, Zibrova D, Green KA, Mustard KJ, Kemp BE, Sakamoto K, Steinberg GR, et al. The ancient drug salicylate directly activates AMPactivated protein kinase. Science. 2012; 336:918-22.

28. Feng Z, Hu W, de Stanchina E, Teresky AK, Jin S, Lowe $\mathrm{S}$, Levine AJ. The regulation of AMPK beta1, TSC2, and PTEN expression by p53: stress, cell and tissue specificity, and the role of these gene products in modulating the IGF1-AKT-mTOR pathways. Cancer Res. 2007; 67:3043-53.

29. Kahn BB, Alquier T, Carling D, Hardie DG. AMP-activated protein kinase: ancient energy gauge provides clues to modern understanding of metabolism. Cell Metab. 2005; 1:15-25.

30. Rios M, Foretz M, Viollet B, Prieto A, Fraga M, Costoya JA, Senaris R. AMPK activation by oncogenesis is required to maintain cancer cell proliferation in astrocytic tumors. Cancer Res. 2013; 73:2628-38. 
31. Rodriguez-Jimnez FJ, Alastrue-Agudo A, Erceg S, Stojkovic M, Moreno-Manzano V. FM19G11 favors spinal cord injury regeneration and stem cell self-renewal by mitochondrial uncoupling and glucose metabolism induction. Stem Cells. 2012; 30:2221-33.

32. Liu L, Ulbrich J, Muller J, Wustefeld T, Aeberhard L, Kress TR, Muthalagu N, Rycak L, Rudalska R, Moll R, Kempa $\mathrm{S}$, Zender L, Eilers M, et al. Deregulated MYC expression induces dependence upon AMPK-related kinase 5. Nature. 2012; 483:608-12.

33. Suzuki A, Lu J, Kusakai G, Kishimoto A, Ogura T, Esumi H. ARK5 is a tumor invasion-associated factor downstream of Akt signaling. Mol Cell Biol. 2004; 24:3526-35.

34. Shaw RJ, Kosmatka M, Bardeesy N, Hurley RL, Witters LA, DePinho RA, Cantley LC. The tumor suppressor LKB1 kinase directly activates AMP-activated kinase and regulates apoptosis in response to energy stress. Proc Natl Acad Sci U S A. 2004; 101:3329-35.

35. Su MY, Hsieh SY, Lee YR, Chang MC, Yuan TT, Chang JM. The relationship between energy status and AMPactivated protein kinase in human H460 lung cancer cells. Cell Biochem Funct. 2010; 28:549-54.

36. Jeon SM, Chandel NS, Hay N. AMPK regulates NADPH homeostasis to promote tumour cell survival during energy stress. Nature. 2012; 485:661-5.

37. Hsu PP, Kang SA, Rameseder J, Zhang Y, Ottina KA, Lim D, Peterson TR, Choi Y, Gray NS, Yaffe MB, Marto JA, Sabatini DM. The mTOR-regulated phosphoproteome reveals a mechanism of mTORC1mediated inhibition of growth factor signaling. Science. 2011; 332:1317-22.

38. Hsu PP, Sabatini DM. Cancer cell metabolism: Warburg and beyond. Cell. 2008; 134:703-7.

39. Carling D, Thornton C, Woods A, Sanders MJ. AMPactivated protein kinase: new regulation, new roles? Biochem J. 2012; 445:11-27.

40. Tong L. Acetyl-coenzyme A carboxylase: crucial metabolic enzyme and attractive target for drug discovery. Cell Mol Life Sci. 2005; 62:1784-803.

41. Foretz M, Carling D, Guichard C, Ferre P, Foufelle F. AMP-activated protein kinase inhibits the glucose-activated expression of fatty acid synthase gene in rat hepatocytes. J Biol Chem. 1998; 273:14767-71.

42. Xiang X, Saha AK, Wen R, Ruderman NB, Luo Z. AMPactivated protein kinase activators can inhibit the growth of prostate cancer cells by multiple mechanisms. Biochem Biophys Res Commun. 2004; 321:161-7.

43. Hay N, Sonenberg N. Upstream and downstream of mTOR. Genes Dev. 2004; 18:1926-45.

44. Shaw RJ. LKB1 and AMP-activated protein kinase control of mTOR signalling and growth. Acta Physiol (Oxf). 2009; 196:65-80.
45. Zoncu R, Efeyan A, Sabatini DM. mTOR: from growth signal integration to cancer, diabetes and ageing. Nat Rev Mol Cell Biol. 2011; 12:21-35.

46. Jalving M, Gietema JA, Lefrandt JD, de Jong S, Reyners AK, Gans RO, de Vries EG. Metformin: taking away the candy for cancer? Eur J Cancer. 2010; 46:2369-80.

47. Owa T, Yoshino H, Yoshimatsu K, Nagasu T. Cell cycle regulation in the G1 phase: a promising target for the development of new chemotherapeutic anticancer agents. Curr Med Chem. 2001; 8:1487-503.

48. Fang Y, Yu H, Liang X, Xu J, Cai X. Chk1-induced CCNB1 overexpression promotes cell proliferation and tumor growth in human colorectal cancer. Cancer Biol Ther. 2014; 15:1268-79.

49. Eichhorn JM, Kothari A, Chambers TC. Cyclin B1 overexpression induces cell death independent of mitotic arrest. PLoS One. 2014; 9:e113283.

50. Sanli T, Steinberg GR, Singh G, Tsakiridis T. AMP-activated protein kinase (AMPK) beyond metabolism: a novel genomic stress sensor participating in the DNA damage response pathway. Cancer Biol Ther. 2014; 15:156-69.

51. Mihaylova MM, Shaw RJ. The AMPK signalling pathway coordinates cell growth, autophagy and metabolism. Nat Cell Biol. 2011; 13:1016-23.

52. Bensimon A, Aebersold R, Shiloh Y. Beyond ATM: the protein kinase landscape of the DNA damage response. FEBS Lett. 2011; 585:1625-39.

53. Storozhuk Y, Hopmans SN, Sanli T, Barron C, Tsiani E, Cutz JC, Pond G, Wright J, Singh G, Tsakiridis T. Metformin inhibits growth and enhances radiation response of non-small cell lung cancer (NSCLC) through ATM and AMPK. Br J Cancer. 2013; 108:2021-32.

54. Sanli T, Rashid A, Liu C, Harding S, Bristow RG, Cutz JC, Singh $\mathrm{G}$, Wright J, Tsakiridis T. Ionizing radiation activates AMP-activated kinase (AMPK): a target for radiosensitization of human cancer cells. Int J Radiat Oncol Biol Phys. 2010; 78:221-9.

55. Jacobson MD. Programmed cell death: a missing link is found. Trends Cell Biol. 1997; 7:467-9.

56. Vaux DL, Korsmeyer SJ. Cell death in development. Cell. 1999; 96:245-54.

57. Hahn-Windgassen A, Nogueira V, Chen CC, Skeen JE, Sonenberg N, Hay N. Akt activates the mammalian target of rapamycin by regulating cellular ATP level and AMPK activity. J Biol Chem. 2005; 280:32081-9.

58. Cui H, Wu S, Shang Y, Li Z, Chen M, Li F, Wang C. Pleurotus nebrodensis polysaccharide (PN50G) evokes A549 cell apoptosis by the ROS/AMPK/PI3K/AKT/mTOR pathway to suppress tumor growth. Food Funct. 2016; 7:1616-27.

59. Okoshi R, Ozaki T, Yamamoto H, Ando K, Koida N, Ono S, Koda T, Kamijo T, Nakagawara A, Kizaki H. Activation of AMP-activated protein kinase induces p53-dependent 
apoptotic cell death in response to energetic stress. J Biol Chem. 2008; 283:3979-87.

60. Hemann MT, Lowe SW. The p53-Bcl-2 connection. Cell Death Differ. 2006; 13:1256-9.

61. Vander Heiden MG, Cantley LC, Thompson CB. Understanding the Warburg effect: the metabolic requirements of cell proliferation. Science. 2009; 324:1029-33.

62. Faubert B, Boily G, Izreig S, Griss T, Samborska B, Dong Z, Dupuy F, Chambers C, Fuerth BJ, Viollet B, Mamer OA, Avizonis D, DeBerardinis RJ, et al. AMPK is a negative regulator of the Warburg effect and suppresses tumor growth in vivo. Cell Metab. 2013; 17:113-24.

63. Xiao B, Sanders MJ, Carmena D, Bright NJ, Haire LF, Underwood E, Patel BR, Heath RB, Walker PA, Hallen S, Giordanetto F, Martin SR, Carling D, et al. Structural basis of AMPK regulation by small molecule activators. Nat Commun. 2013; 4:3017.

64. Hawley SA, Davison M, Woods A, Davies SP, Beri RK, Carling D, Hardie DG. Characterization of the AMP-activated protein kinase kinase from rat liver and identification of threonine 172 as the major site at which it phosphorylates AMP-activated protein kinase. J Biol Chem. 1996; 271:27879-87.

65. Sujobert P, Poulain L, Paubelle E, Zylbersztejn F, Grenier A, Lambert M, Townsend EC, Brusq JM, Nicodeme E, Decrooqc J, Nepstad I, Green AS, Mondesir J, et al. Co-activation of AMPK and mTORC1 Induces Cytotoxicity in Acute Myeloid Leukemia. Cell Rep. 2015; 11:1446-57.

66. Pang T, Zhang ZS, Gu M, Qiu BY, Yu LF, Cao PR, Shao W, Su MB, Li JY, Nan FJ, Li J. Small molecule antagonizes autoinhibition and activates AMP-activated protein kinase in cells. J Biol Chem. 2008; 283:16051-60.

67. Jensen TE, Ross FA, Kleinert M, Sylow L, Knudsen JR, Gowans GJ, Hardie DG, Richter EA. PT-1 selectively activates AMPK-gammal complexes in mouse skeletal muscle, but activates all three gamma subunit complexes in cultured human cells by inhibiting the respiratory chain. Biochem J. 2015; 467:461-72.

68. Trikha P, Plews RL, Stiff A, Gautam S, Hsu V, Abood D, Wesolowski R, Landi I, Mo X, Phay J, Chen CS, Byrd J, Caligiuri $\mathrm{M}$, et al. Targeting myeloid-derived suppressor cells using a novel adenosine monophosphate-activated protein kinase (AMPK) activator. Oncoimmunology. 2016; 5:e1214787.

69. Plews RL, Mohd Yusof A, Wang C, Saji M, Zhang X, Chen CS, Ringel MD, Phay JE. A novel dual AMPK activator/ mTOR inhibitor inhibits thyroid cancer cell growth. J Clin Endocrinol Metab. 2015; 100:E748-56.

70. Chou CC, Lee KH, Lai IL, Wang D, Mo X, Kulp SK, Shapiro CL, Chen CS. AMPK reverses the mesenchymal phenotype of cancer cells by targeting the Akt-MDM2Foxo3a signaling axis. Cancer Res. 2014; 74:4783-95.

71. Lee KH, Hsu EC, Guh JH, Yang HC, Wang D, Kulp SK, Shapiro CL, Chen CS. Targeting energy metabolic and oncogenic signaling pathways in triple-negative breast cancer by a novel adenosine monophosphate-activated protein kinase (AMPK) activator. J Biol Chem. 2011; 286:39247-58.

72. Hunter RW, Foretz M, Bultot L, Fullerton MD, Deak M, Ross FA, Hawley SA, Shpiro N, Viollet B, Barron D, Kemp BE, Steinberg GR, Hardie DG, et al. Mechanism of action of compound-13: an alpha1-selective small molecule activator of AMPK. Chem Biol. 2014; 21:866-79.

73. Zhao H, Zhu H, Lin Z, Lin G, Lv G. Compound 13, an alpha1-selective small molecule activator of AMPK, inhibits Helicobacter pylori-induced oxidative stresses and gastric epithelial cell apoptosis. Biochem Biophys Res Commun. 2015; 463:510-7.

74. Liao CR, Kuo YH, Ho YL, Wang CY, Yang CS, Lin CW, Chang YS. Studies on cytotoxic constituents from the leaves of Elaeagnus oldhamii Maxim. in non-small cell lung cancer A549 cells. Molecules. 2014; 19:9515-34.

75. Zadra G, Photopoulos C, Tyekucheva S, Heidari P, Weng QP, Fedele G, Liu H, Scaglia N, Priolo C, Sicinska E, Mahmood U, Signoretti S, Birnberg N, et al. A novel direct activator of AMPK inhibits prostate cancer growth by blocking lipogenesis. EMBO Mol Med. 2014; 6:519-38.

76. Anil TM, Harish C, Lakshmi MN, Harsha K, Onkaramurthy M, Sathish Kumar V, Shree N, Geetha V, Balamurali GV, Gopala AS, Madhusudhan Reddy B, Govind MK, Anup MO, et al. CNX-012-570, a direct AMPK activator provides strong glycemic and lipid control along with significant reduction in body weight; studies from both diet-induced obese mice and $\mathrm{db} / \mathrm{db}$ mice models. Cardiovasc Diabetol. 2014; 13:27. 